\title{
Zinc Supplementation Attenuated Calcium-High Diet Effect on Zinc Status and Carbohydrate Metabolism of Non-Diabetic and Diabetic Rats \\ Samir Derouiche and Zine Kechrid ${ }^{*}$
}

Faculty of Sciences, Department of Biochemistry, Laboratory of Biochemistry and Applied Microbiology, University Badji Mokhtar-Annaba, Algeria

*Corresponding author: Pr. Zine Kechrid, Faculty of Sciences, Department of Biochemistry, Laboratory of Biochemistry and Applied Microbiology, University Badji Mokhtar-Annaba, Annaba 23000, Algeria, Tel: 00213-773345102

\begin{abstract}
Background: The bioavailability of zinc can be influenced by several dietary factors, among them calcium level, which leads to zinc metabolism disturbance. Thus, the present study was under taken to evaluate the effect of zinc supplementation on zinc status and carbohydrate metabolism in non-diabetic and diabetic rats fed high-calcium diet.

Methods: Sixty male Wistar rats were randomly divided into six equal groups. The first and fourth groups were non-diabetic and diabetic controls respectively. The second, third, fifth and sixth groups were calcium, calcium + zinc, diabetes + calcium and diabetes + calcium + zinc groups, respectively. Diabetes in fourth, fifth and sixth groups were induced by alloxan. Calcium ( $35 \mathrm{mg} / \mathrm{kg}$ feed) as $\mathrm{CaCO}_{3}$ and zinc (231 mg/kg feed) as $\mathrm{ZnSO}_{4} 7 \mathrm{H}_{2} \mathrm{O}$ in feed were supplemented to the animals in groups for 21 days.

Results: High dietary calcium significantly decreased body weight gain, serum zinc, tissue zinc levels, alkaline phosphatase, lactic dehydrogenases and aldolase activities and led to an increase of cholesterol, transaminases and uric acid concentrations in both diabetic and non-diabetic rats. However, zinc supplementation in animals fed calcium assured a partial correction of the previous parameters.

Conclusion: The investigation revealed that zinc supplementation has a positive role against the negative effect of calcium, which provoked metabolic disturbance in diabetic and non-diabetic rats.
\end{abstract}

\section{Keywords}

Diabetes, Rats, Zinc, Calcium, Aldolase

\section{Introduction}

Diabetes is a group of metabolic disorders characterized by chronic hyperglycemia resulting from disorders of secretion or the action of insulin. This hyperglycemia is associated with long-term complications, dysfunction of various organs, especially the eyes, kidneys, nerves, heart and blood vessels [1]. There is a high degree of reciprocity of the relationship between diabetes and minerals, especially in the case of uncontrolled chronic hyperglycemia, which can cause remarkable alterations in the state of these nutrients, and vice versa [2]. Some of these substances, particularly those that have been characterized as micronutrients, can directly modulate glucose homeostasis [3]. Zinc is one of the important essential trace elements that are required for many cell events as cofactor of numerous enzymes. Indeed zinc is present in the catalytic site of many enzymes; if zinc is removed, the catalytic efficiency drops to zero. Zinc-containing enzymes belong to all six classes of enzymes: hydrolases (alkaline phosphatase), isomerases, ligases (DNA ligases), lyases (aldolase), oxidoreductases (lactic dehydrogenase), and transferase (cobalamin-dependent methionine synthase) [4]. These enzymes are involved with the metabolism of proteins, carbohydrates and lipids [5]. A relationship between zinc and insulin storage is also suggested by the findings that acute stimulation of insulin secretion in rats also reduces the zinc content in $B$ cells of the pancreas [6]. In other words, during the secretion of insulin, it is necessary to

Citation: Derouiche S, Kechrid Z (2018) Zinc Supplementation Attenuated Calcium-High Diet Effect on Zinc Status and Carbohydrate Metabolism of Non-Diabetic and Diabetic Rats. Int J Diabetes Clin Res 5:095. doi.org/10.23937/2377-3634/1410095

Accepted: October 01, 2018: Published: October 03, 2018

Copyright: (C) 2018 Derouiche S, et al. This is an open-access article distributed under the terms of the Creative Commons Attribution License, which permits unrestricted use, distribution, and reproduction in any medium, provided the original author and source are credited. 
be stored in vesicles or granules, where two $\mathrm{Zn}^{2+}$ ions coordinate six insulin monomers to form the hexameric structure, which is the basis of the insulin maturation under crystal forms [7]. Thus, zinc deficiency is always related to certain disorders such as metabolic syndrome and diabetic complications, which characterized by an abnormally high concentration of blood glucose (hyperglycemia). The later leads to diabetes development [8]. It was also documented that inadequate zinc seems to be associated with the pathogenesis of type 2 diabetes mellitus (DM), supporting the notion that $\mathrm{Zn}$ deficiency may result in the exacerbation of insulin resistance [9]. Diabetes usually leads to hypozincemia and a decrease in tissue zinc stores [10]. The possible reasons for decreasing serum zinc concentration in diabetic patients are malabsorption and excessive urinary excretion. So there are several reasons for suspecting that an abnormal zinc metabolism could play a role in the pathogenesis of diabetes mellitus and some of its complications [11]. Calcium plays many biological roles in the organism, mainly in skeletal structure, blood coagulation, nervous system function, muscle contraction and enzyme activities. Calcium is an essential element; therefore the bioavailability in the organism is generally insured by the food stuff [12]. Calcium status depends on the state of calcium metabolism, which is regulated by mechanisms including hormonal homeostasis, intestinal absorption, renal reabsorption and bone turnover. The hormonal part of regulation mechanism is based on parathyroid hormone (PTH), dihydroxyvitamin D, ionized calcium itself, and their corresponding receptors in the gut, kidney and bone [13]. One of the most common trace metal imbalances is elevated calcium and depressed zinc or the inverse [14-16]. In that case, calcium has been indicated to reduce the passive action movements via shunt pathways in the gallbladder mucosa. So the possibility that calcium in high luminal concentration may depress zinc absorption by reducing the passive component of jejunal zincs absorption [17]. It was indicated that high calcium diets can reduce net zinc absorption and balance and may increase the zinc requirement [18]. Bellis and Philips [19] observed also that the addition of calcium to a low zinc diet led to a further depression in growth and increased the severity of parakeratosis skin lesions in swine. Thus, the aim of this study was to examine the effect of dietary zinc supplementation on diabetic pathology observed in rats with alloxan-induced diabetes that were fed a high calcium content feed by evaluating body weight gain, food intake, zinc status and carbohydrate metabolism.

\section{Materials and Methods}

\section{Animals}

Albino Wistar rats of age 10-12 weeks of age and weighing 230-290 g were obtained from the Pasteur Institute, Algiers. Prior to experiments, the animals were allowed to acclimate to their surroundings for one week.
Animals were housed in individual plastic cages with bedding. Trays were placed under each food hopper to collect spilled food. The temperature was maintained at $22^{\circ} \pm 2{ }^{\circ} \mathrm{C}$. A $12 / 12$-hour light/dark cycle was maintained, with lights on at 6 am unless otherwise noted. Humidity was around $40 \%$. Standard rat diet [20] and water were available ad libitum for the duration of the experiments. The diet consisted (in grams per kg of diet) of cornstarch 326, sucrose 326, proteins 168 (egg-white solids), lipids 80 (corn oil), fibre 40 (cellulose), vitamin mix (sigma) and mineral mix 40. The latter was formulated to contain normal adequate quantities of zinc (54 $\mathrm{mg} \mathrm{Zn/kg} \mathrm{diet).} \mathrm{Zinc} \mathrm{level} \mathrm{were} \mathrm{checked} \mathrm{in} \mathrm{duplicate} \mathrm{of} 2$ $\mathrm{g}$ in diet, utilizing flame atomic absorption spectrophotometer as described in serum and tissue zinc analyses section. The mineral mix was supplied (in grams per kg of diet) as calcium hydrogen orthophosphate, 13; disodium hydrogen orthophosphate, 7.4 ; calcium carbonate, 8.2; potassium chloride, 7.03; magnesium sulphate, 4; ferrous sulphate, 0.144; copper sulphate, 0.023; potassium iodide, 0.001; manganese sulphate, 0.180; and zinc carbonate, 0.1 .

\section{Induction of diabetes}

Diabetes was induced by injection of alloxan intraperitoneally (i.p.) at a dose of $150 \mathrm{mg} / \mathrm{kg}$ body weight. The solution of the alloxane monohydrate is freshly dissolved in citrate buffer (0.01 M, pH 4.5) according to the method described by Fatmi, et al. [21]. Blood glucose was measured 7 days after the induction of diabetes on samples taken from the tail vein. Diabetes was established when the glucose concentration exceeded 14 $\mathrm{mmol} / \mathrm{l}$ confirmed by a glucometer (Accu-Check, Roche Diagnostics, Paris, France).

\section{Experimental design}

After the successful induction of experimental diabetes, rats were randomly divided into six groups, ten each. The first and fourth groups were non-diabetic and diabetic controls respectively. The second, third, fifth and sixth groups were non-diabetic+calcium, non-diabetic+calcium+zinc, diabetes+calcium and diabetes+calcium+zinc groups, respectively. Calcium (35 g/ kg feed) as $\mathrm{CaCO}_{3}$ [22] and zinc (231 mg/kg feed) as $\mathrm{ZnSO}_{4} 7 \mathrm{H}_{2} \mathrm{O}$ [23] in feed were supplemented to the animals in calcium and zinc groups. Animals were maintained on the appropriate experimental diet for 21 days. Body weight and food intake were recorded regularly. The animals were maintained and used in accordance with the Animal Welfare Act and the Guide for the Care and Use of Laboratory Animals prepared by Annaba University.

\section{Samples collection}

On the 22nd day, animals were killed by cervical cut under ether anesthesia. Blood samples were transferred into ice cold centrifuge tubes. The serum was obtained by centrifugation at $3000 \mathrm{rpm}$ for $10 \mathrm{~min}$ and utilized for the determination of serum zinc, aldolase, aspartate aminotran- 
sferase (AST) and alanine aminotransferase (ALT), alkaline phosphatase (ALP), total proteins, cholesterol, urea, uric acid, lactate dehydrogenase (LDH). Pancreas, kidneys, and liver were dried at $80^{\circ} \mathrm{C}$ for $16 \mathrm{~h}$ for zinc determination.

\section{Measurement of biochemical parameters}

The serum cholesterol, total proteins, urea, uric acid, glutamic pyruvic transaminase (GPT), glutamic oxaloacetic transaminase (GOT), alkaline phosphatase (ALP), lactate dehydrogenase (LDH) and aldolase were measured using Spinreact Laboratory Spain diagnostic kits and spectrophotometer (Jenway 6505, Jenway LTD, Essex, UK). The references of kits were as follow: cholesterol-1001093, total proteins-1001291, urea-1002120, uric acid-1001013, ALP-1001131, GOT-1001161, LDH1001260, GPT-1001171 and aldolase-1001075.

\section{Serum and tissue zinc analyses}

Dried pancreas, kidney and liver were weighed into silica crucibles, charred and ashed in a muffle furnace at $480{ }^{\circ} \mathrm{C}$ for $48 \mathrm{~h}$; the resulting ash was dissolved in hydrochloric acid $(12 \mathrm{M})$. Then tissues zinc was measured by flame atomic absorption spectrophotometer (Shimadzu AA-6200; Somerset, New Jersey, USA). Standard reference materials of bovine liver and wheat flour were used to check the accuracy of zinc recovery, which exceeded $96 \%$ in the reference material and serum zinc was estimated after 20 folds dilution. Zinc standards were prepared from $1 \mathrm{mg} / \mathrm{ml}$ zinc nitrate solution, using $5 \%$ glycerol to approximate the viscosity [24].

\section{Statistics}

Results were expressed as mean \pm SEM. The comparison of the results was performed using a one-way analysis of variance. Differences were considered statistically significant at $p<0.05$.

\section{Results}

\section{Effect of treatments on body weight and food intake}

Induction of a type I diabetic state caused a decrease in body weight gain and an increase of food intake in the diabetic rats compared to the non-diabetic rats. Meanwhile, high calcium feed reduced body weight and food intake respectively by $(-8.34 \%,-8.87 \%)$ of non-diabetic and $(-11.66 \%,-4.67 \%)$ of diabetic rats, while zinc supplementation reversed these changes (Table 1 ).

\section{Effect of treatments on zinc levels}

Table 2 shows that serum zinc, liver zinc and testis zinc contents were significantly lower $(p<0.01, p$ $<0.001$ ) in the diabetic group than the non-diabetic group. Calcium treatment in both diabetic and non-diabetic rats resulted also in a decrease of serum and tissues zinc concentrations. However, zinc supplementation restored zinc concentrations in both non-diabetic and diabetic animals given high calcium feed.

\section{Effect of treatments on serum biochemical para- meters}

As shown in Table 3, diabetes caused significant increase of serum glucose (91.23\%), cholesterol (8.22\%), urea $(46.34 \%)$ and uric acid (25.03\%) concentrations and a significant decrease of serum total proteins level $(-17.75 \%)$. Meanwhile, high calcium feed led to high glucose $(16.52 \%)$, cholesterol $(9.68 \%)$, serum urea (19.61) and serum uric acid (2.92\%) concentrations in non-diabetic rats. Diabetic animals fed also on high calcium feed had high blood glucose (10.37\%), serum cholesterol (4.67\%), serum urea (7.2) and serum uric acid (8.23\%) as compares to diabetic animals. Simultaneously, zinc supplementation ameliorated the above mentioned biochemical parameters, either in non-diabetic or diabetic rats.

Table 1: Mean initial body weight $(\mathrm{g})$, final body weight gain $(\mathrm{g})$ and food intake ( $\mathrm{g} /$ day/rat) of control and experimental animals.

\begin{tabular}{|c|c|c|c|c|c|c|}
\hline Parameters & $\begin{array}{l}\text { Control } \\
(n=10)\end{array}$ & $\begin{array}{l}\text { Non-diabetic+Ca } \\
(\mathrm{n}=10)\end{array}$ & $\begin{array}{l}\text { Non-diabetic+Ca+Zn } \\
(n=10)\end{array}$ & $\begin{array}{l}\text { Diabetic } \\
(n=10)\end{array}$ & $\begin{array}{l}\text { Diabetic+Ca } \\
(n=10)\end{array}$ & $\begin{array}{l}\text { Diabetic+Ca+Zn } \\
(n=10)\end{array}$ \\
\hline Initial Body weight & $274.3 \pm 1.9$ & $283.5 \pm 3.1$ & $270.3 \pm 4.2$ & $282.7 \pm 2.4$ & $285.1 \pm 2.9$ & $281.9 \pm 2.7$ \\
\hline Final body weight & $378.8 \pm 4.42$ & $347.2 \pm 4.84^{* * *}$ & $367.6 \pm 3.4^{\mathrm{a} 1}$ & $268.3 \pm 7.51^{* \star *}$ & $237 \pm 5.92^{* * * \mathrm{~b} 2}$ & $266.3 \pm 5.21^{* * * *} \mathrm{c} 2$ \\
\hline Food intake & $12.4 \pm 0.18$ & $11.3 \pm 0.25^{* \star}$ & $12.62 \pm 0.05^{\mathrm{a} 1}$ & $17.10 \pm 0.07^{\star \star \star}$ & $16.3 \pm 0.21^{* * * \mathrm{~b} 1}$ & $17.62 \pm 0.15^{* * *+c 2}$ \\
\hline
\end{tabular}

Values are mean \pm SEM, $\mathrm{n}=$ number of samples.

${ }^{* *} p<0.01$; ${ }^{* * *} p<0.001$ : all groups versus control group; ${ }^{a 1} p<0.01$ : non-diabetic+Ca+Zn versus non-diabetic calcium group; ${ }^{b 1} p<$ $0.01 ;{ }^{b 2} p<0.001$ : diabetic+Ca versus diabetic group; ${ }^{c 2} p<0.001$ : diabetic $+C a+Z n$ versus diabetic calcium group.

Table 2: Zinc concentrations in serum $(\mu \mathrm{g} / 100 \mathrm{ml})$ and tissues $(\mu \mathrm{g} / \mathrm{g}$ dry weight) of control and experimental animals.

\begin{tabular}{|c|c|c|c|c|c|c|}
\hline Parameters & $\begin{array}{l}\text { Control } \\
(n=10)\end{array}$ & $\begin{array}{l}\text { Non-diabetic+Ca } \\
(n=10)\end{array}$ & $\begin{array}{l}\text { Non-diabetic+Ca+Zn } \\
(n=10)\end{array}$ & $\begin{array}{l}\text { Diabetic } \\
(n=10)\end{array}$ & $\begin{array}{l}\text { Diabetic+Ca } \\
(n=10)\end{array}$ & $\begin{array}{l}\text { Diabetic+Ca+Zn } \\
(n=10)\end{array}$ \\
\hline Serum & $153.80 \pm 3.10$ & $137.50 \pm 1.61^{*}$ & $161.80 \pm 3.02^{*} \mathrm{a} 2$ & $90.30 \pm 1.43^{* * *}$ & $81.1 \pm 1.22^{* * *} b 1$ & $102.31 \pm 2.54^{* \star *} c 2$ \\
\hline Liver & $35.19 \pm 1.75$ & $31.83 \pm 1.74^{*}$ & $40.51 \pm 1.35^{*}{ }^{21}$ & $28.59 \pm 1.18^{* *}$ & $24.54 \pm 0.91^{* * * b}$ & $30.86 \pm 0.70^{*} \mathrm{c} 1$ \\
\hline Kidney & $39.70 \pm 1.31$ & $34.35 \pm 1.68^{*}$ & $46.20 \pm 1.91^{* \mathrm{a} 2}$ & $35.19 \pm 0.82$ & $32.0 \pm 0.78^{\star \star \star b}$ & $42.00 \pm 1.26^{*} \mathrm{c} 2$ \\
\hline Pancreas & $61.06 \pm 1.55$ & $56.41 \pm 2.03^{*}$ & $64.53 \pm 2.68^{\mathrm{a} 1}$ & $59.82 \pm 1.39$ & $55.01 \pm 5.03^{* * b 1}$ & $63.41 \pm 2.01^{\mathrm{c} 1}$ \\
\hline
\end{tabular}

Values are mean \pm SEM, $n=$ number of samples.

${ }^{*} p<0.05$; " $p<0.01$; ${ }^{* *} p<0.001$ : all groups versus control group; ${ }^{a 1} p<0.01$; ${ }^{2} p<0.001$ : non-diabetic+Ca+Zn versus non-diabetic calcium group; ${ }^{b} p<0.05$; ${ }^{b 1} p<0.01$ : diabetic $+C a$ versus diabetic group; ${ }^{c 1} p<0.01$; ${ }^{c 2} p<0.001$ : diabetic $+C a+Z n$ versus diabetic calcium group. 
Table 3: Mean blood glucose (mmol/l), serum cholesterol (mg/dl), protein $(\mathrm{g} / \mathrm{dl})$, urea $(\mathrm{mg} / \mathrm{dl})$ and uric acid (mg/dl) concentrations of control and experimental animals.

\begin{tabular}{|c|c|c|c|c|c|c|}
\hline Parameters & $\begin{array}{l}\text { Control } \\
(n=10)\end{array}$ & $\begin{array}{l}\text { Non-diabetic+Ca } \\
(\mathrm{n}=10)\end{array}$ & $\begin{array}{l}\text { Non-diabetic+Ca+Zn } \\
(n=10)\end{array}$ & $\begin{array}{l}\text { Diabetic } \\
(n=10)\end{array}$ & $\begin{array}{l}\text { Diabetic+Ca } \\
(n=10)\end{array}$ & $\begin{array}{l}\text { Diabetic+Ca+Zn } \\
(n=10)\end{array}$ \\
\hline Glucose & $6.05 \pm 0.15$ & $7.05 \pm 0.38^{*}$ & $5.44 \pm 0.13^{*} \mathrm{a} 1$ & $11.57 \pm 0.16^{* * *}$ & $12.77 \pm 0.28^{\star \star *} \mathrm{~b} 1$ & $9.61 \pm 0.12^{* * c 1}$ \\
\hline Cholesterol & $158 \pm 5.2$ & $173.3 \pm 3.9^{*}$ & $167 \pm 3.49^{* a}$ & $171 \pm 2.5^{* \star *}$ & $179.0 \pm 4.0^{* * * t b 1}$ & $161 \pm 2.7^{\mathrm{c} 2}$ \\
\hline Protein & $8.45 \pm 0.05$ & $8.34 \pm 0.18$ & $8.49 \pm 0.25$ & $6.95 \pm 0.11^{* \star *}$ & $7.07 \pm 0.16^{\star *}$ & $7.85 \pm 0.23^{* \star c} c$ \\
\hline Urea & $41.8 \pm 1.17$ & $50 \pm 2.62^{* \star *}$ & $32.6 \pm 1.42^{* * * a 2}$ & $61.1 \pm 0.83^{* \star *}$ & $65.5 \pm 1.53^{* * * t b 1}$ & $52 \pm 2.18^{* * *} \mathrm{c} 2$ \\
\hline Uric acid & $7.19 \pm 0.21$ & $7.44 \pm 0.2^{*}$ & $7.10 \pm 0.35^{a}$ & $8.99 \pm 0.19^{* * *}$ & $9.73 \pm 0.22^{* * * b 1}$ & $9.15 \pm 0.36^{\star *} \mathrm{c} 2$ \\
\hline
\end{tabular}

Values are mean \pm SEM, $n=$ number of samples.

${ }^{*} p<0.05 ;{ }^{* *} p<0.01 ;{ }^{* * *} p<0.001$ : all groups versus control group; ${ }^{a} p<0.05 ;{ }^{a 1} p<0.01 ;{ }^{a 2} p<0.001$ : non-diabetic+Ca+Zn versus non-diabetic calcium group; ${ }^{b 1} p<0.01$ : diabetic + Ca versus diabetic group; ${ }^{c} p<0.05 ;{ }^{c 1} p<0.01 ;{ }^{c 2} p<0.001$ : diabetic+Ca+Zn versus diabetic calcium group.
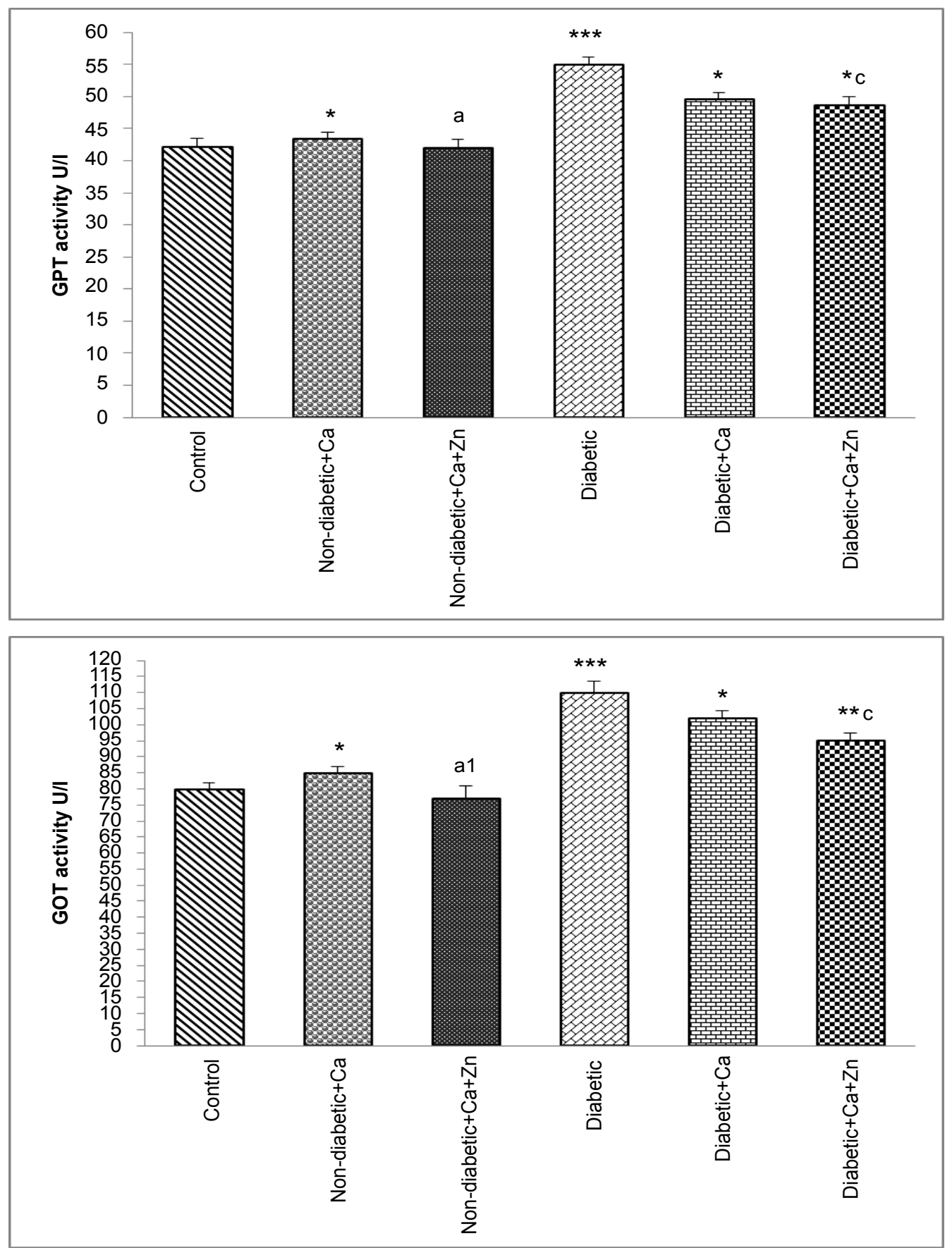

Figure 1: Glutamate-pyruvate transaminase (GPT) and glutamate-oxaloacetate transaminase (GOT) activities of control and experimental animals.

Values are mean \pm SEM, $\mathrm{n}=10$.

${ }^{*} p<0.05$; " $p<0.01$; "** $p<0.001$ : all groups versus control group; a $p<0.05$; a1 $p<0.01$ : non-diabetic+Ca+Zn versus non-diabetic calcium group; ${ }^{c} p<0.05$ : diabetic $+\mathrm{Ca}+\mathrm{Zn}$ versus diabetic calcium group. 


\section{Effect of treatments on enzymatic activities}

As indicated in Figure 1, Figure 2 and Figure 3, diabetes resulted in a significant increase $(p<0.001)$ of serum GOT and GPT activities and a decrease $(p<0.001)$ of serum ALP, aldolase and LDH activities. In addition, calcium supplementation produced a decrease of ALP in non-diabetic animals and both LDH and aldolase in diabetic animals. However, zinc supplementation restored these enzymes activities.

\section{Discussion}

The results obtained in this experiment showed that diabetes body gain was less than that of the control rats, which is consistent with several previously published studies $[25,26]$. This indicates the possibility of metabolic disturbance in animals, suggesting that the diabetic state has been exacerbated to reduce the ability of diabetic rats to use food as normal subjects. Meanwhile, a noticeable calcium effect on body weight gain and food consumption was observed. These results might be due to high dietary calcium intake, which depresses the levels of PTH and 1, 25-hydroxy vitamin D, thereby causing lower levels of intracellular calcium, inhibiting lipogenesis and stimulating lipolysis [27]. In addition, calcium may reduce zinc absorption, which has a major role in appetite regulation through leptin biosynthesis and its receptor at the hypothalamic level [28]. Moreover, zinc can increase the growth factor I (IGF-I) level to enhance serum testosterone secretion. Hence, both IGF-I and testosterone are anabolic factors that
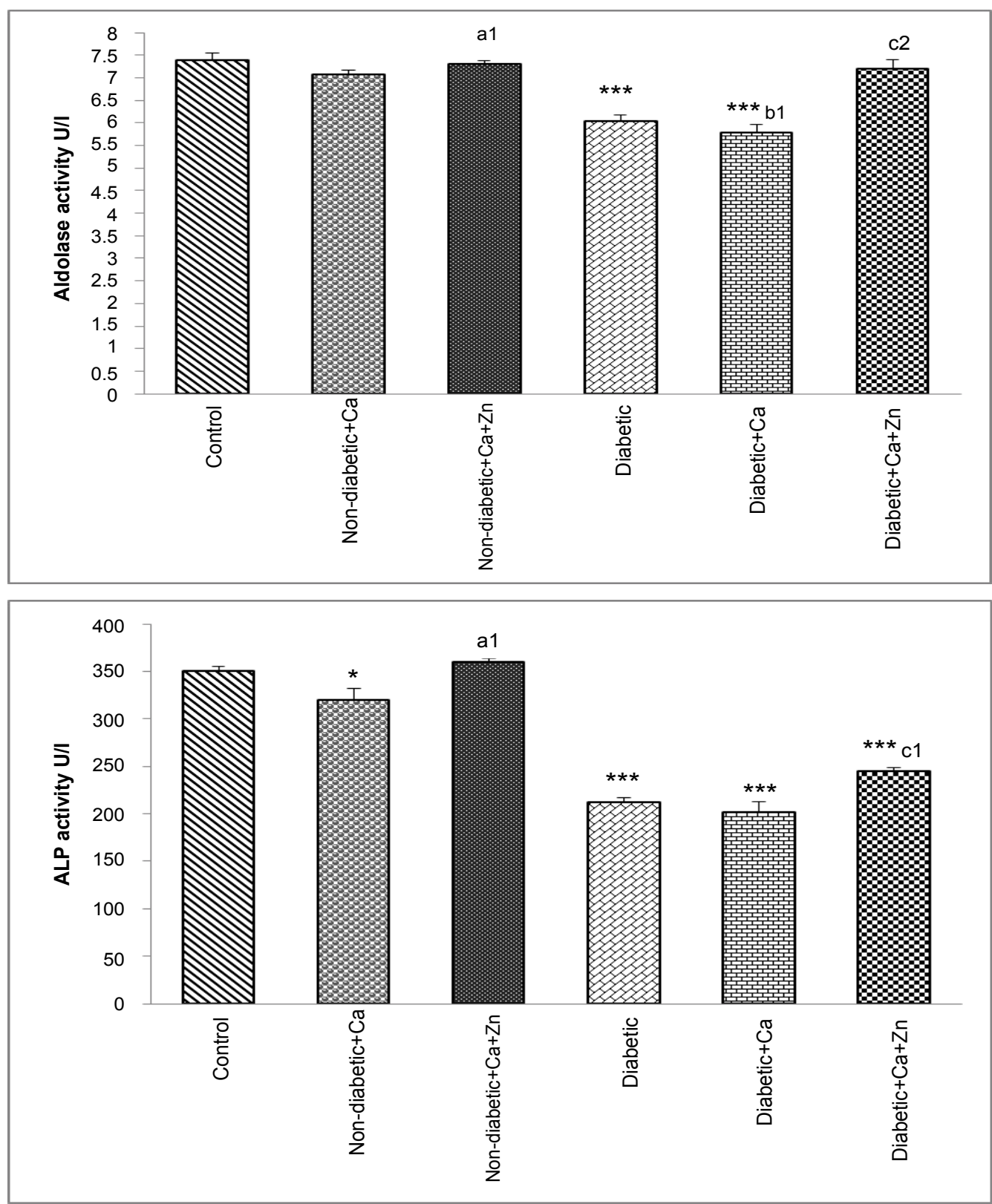

Figure 2: Aldolase, alkaline phosphatase (ALP) and lactate dehydrogenase (LDH) activities in serum of control and experimental animals.

Values are mean $\pm \mathrm{SEM}, \mathrm{n}=10$.

" $p<0.05 ;{ }^{* * *} p<0.001$ : all groups versus control group; ${ }^{a 1} p<0.01$ : non-diabetic+Ca+Zn versus non-diabetic calcium group; ${ }^{b 1} p$ $<0.01$ : diabetic+Ca versus diabetic group; ${ }^{c 1} \mathrm{p}<0.01$; ${ }^{\mathrm{c}} \mathrm{p}<0.001$ : diabetic $+\mathrm{Ca}+\mathrm{Zn}$ versus diabetic calcium group. 


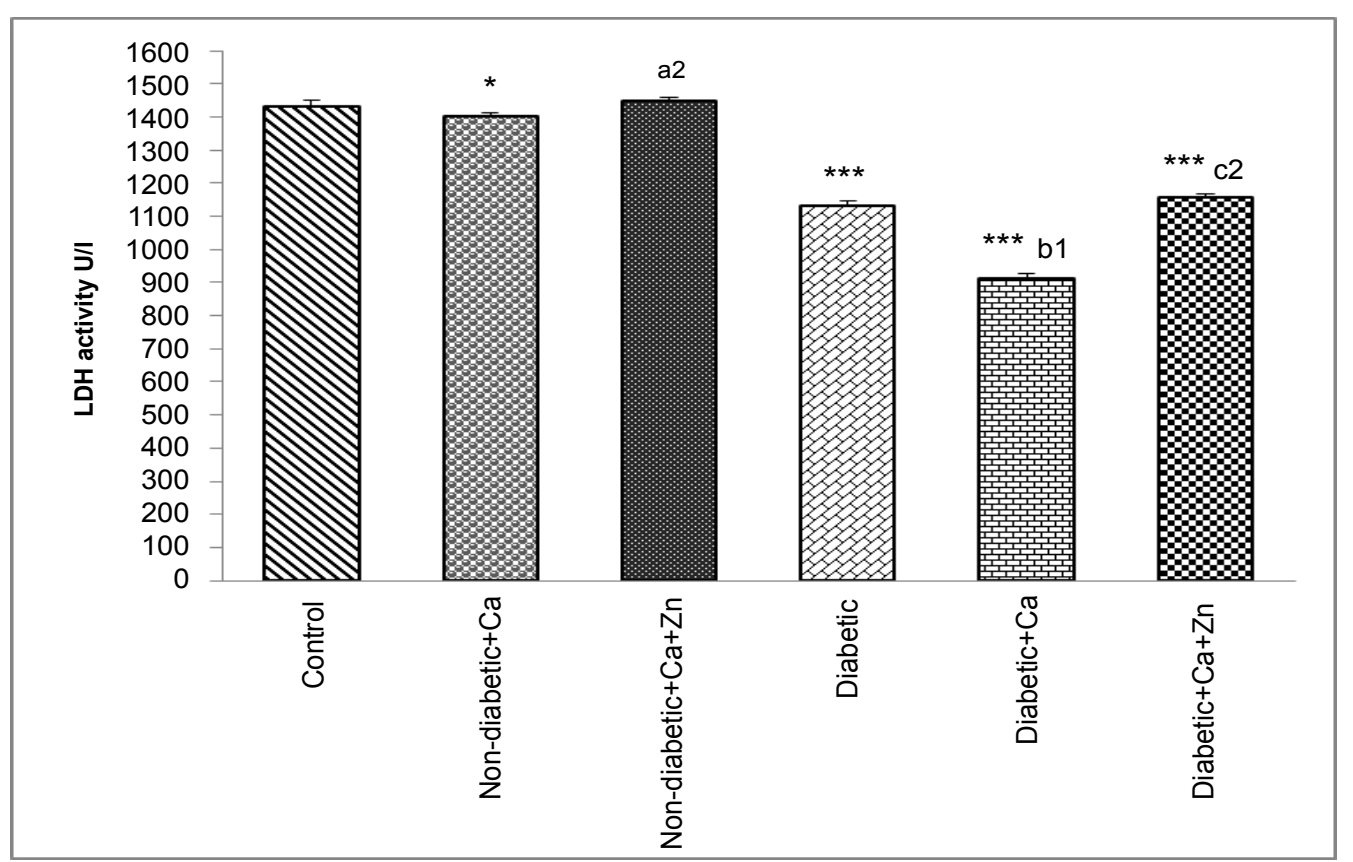

Figure 3: Lactate dehydrogenase (LDH) activity in serum of control and experimental animals.

Values are mean \pm SEM, $\mathrm{n}=10$.

" $p<0.05 ;{ }^{* * *} p<0.001$ : all groups versus control group; ${ }^{2} p<0.001$ : non-diabetic+Ca+Zn versus non-diabetic calcium group; ${ }^{b 1} p<0.01$ : diabetic+Ca versus diabetic group; ${ }^{c 2} p<0.001$ : diabetic $+\mathrm{Ca}+\mathrm{Zn}$ versus diabetic calcium group.

can improve body weight gain [29]. Serum and tissue zinc levels of diabetic rats were lower than in non-diabetics, indicating the effect of disease on zinc status. It has been reported that excessive urinary and gastrointestinal malabsorption of zinc is a characteristic symptom for diabetics [30]. Simultaneously, high diet calcium has led to low serum and tissues zinc in non-diabetic and diabetic animals. These findings, confirm that calcium affect the bioavailability of the zinc. An inhibitory effect of calcium on zinc utilization has been reported by Chao, et al. [31]. In this respect, the results of the present study are also in conformity with the finding of Mace and Shannon [32]. Likewise, with zinc supplementation, a total correction of zinc status in non-diabetic and diabetic rats was observed. These results agree with the investigation of Spencer, et al. [15], who found that high zinc intake decreased the intestinal absorption of calcium. Results of recent studies have indicated also that zinc supplementation causes stimulation of metallothionein synthesis [33], because it facilitates zinc absorption. The mean fasting blood glucose concentration in rats fed high calcium ration were found to be higher than those of diabetic and non-diabetic rats fed standard diet, which suggest that calcium reduced zinc-free levels [18]. Thus, the reduction of zinc exacerbated the capacity of rats fed calcium to utilize glucose in tissues or to an increased rate of endogenous glucose biosynthesis [26]. Because zinc plays an important role in the synthesis, storage and secretion of insulin as well as the conformational hormone integrity in the hexametric form. The decreased zinc affects the ability of the islet cells to produce and secrete insulin [34,35], which justifies the hyperglycemia induced by calcium-high diet.
This suggests that abnormal calcium level is reportedly associated with the development of diabetes, impaired glucose tolerance, and insulin resistance [36,37]. Meanwhile, the current research showed that glucose concentration was ameliorated after zinc supplementation in both non-diabetic and diabetic calcium animals. Zinc intervenes in the regulation of blood glucose concentration by several molecular mechanisms after zinc supplementation. The protein tyrosine phosphatase $1 \mathrm{~B}$ (PTP 1B), a key regulator of the phosphorylation state of insulin receptor, is known to be a target of zinc-ion activation [38]. Studies have also mentioned that zinc may play a role in improving peripheral insulin sensitivity, because it can potentiate insulin, which stimulates glucose transport [34]. Furthermore, zinc decreases glucose absorption and synthesis while promoting glucose metabolism and storage. This occurs primarily via the activation of enzymes involved in these metabolic processes, such as alpha-glucosidase, phosphofructokinase (PFK), phosphokinase (PK) and glycogen synthase [39]. The cholesterol and uric acid levels of animals that received high calcium feed were significantly higher than those of non-diabetic and diabetic controls. These findings indicate that lipids, proteins and nucleic acids metabolism are sensitive to zinc variation. The oral treatment of non-diabetic and diabetic by calcium with zinc has decreased obviously cholesterol and uric acid levels. Thus, it indicates that zinc mobilises and activates the carbohydrate metabolism of these animals. In other words, it has been stated that several enzymes involved in the metabolism of carbohydrates are depending on zinc activation [5]. The noticed increase in serum AST and ALT activities of diabetic rats could be related to 
the accumulation of substrates of these enzymes (glutamic acid and alanine) in the serum of diabetic animals following the use of amino acids from protein stores as an energy source $[40,41]$. These enzymes are required to convert excess amino acids into ketone bodies ( $\alpha$-keto-glutaric and pyruvate), which explain the increase in their activities. In addition, the higher activity of AST of non-diabetic animals fed high calcium diet confirms the results of high blood glucose concentration. In other words, the gluconeogenetic action of AST plays a role by providing new supply of glucose from other sources such as amino acids. Grefley and Sandstead [42] found a decrease in the oxidation of carbon chain of alanine and the later was accumulated in the blood of animals fed zinc deficiency diet. The decrease in serum alkaline phosphatase and aldolase activities (zinc dependent enzymes) in the diabetic compared to non-diabetic rats was certainly due to malabsorption and excessive zinc urinary excretion, which are responsible for zinc reduction. The later was present in several metalloenzymes and, hence, it is needed for their activities. The decline of the previous enzymatic activities in calcium-fed rats can be explained by the decrease in serum zinc following competition with excess dietary calcium. Zinc is essential for the activity of aldolase [43], lactate dehydrogenase [23] and alkaline phosphatase [44] as a mineral cofactor. It serves as one or more catalytic, regulatory or structural functions at the active site of these enzymes. An investigation by Sarker and Satoh [45] confirmed that plasma alkaline phosphate activity was significantly higher in the zinc-supplemented group than in the control.

\section{Conclusion}

To conclude, high dietary calcium intake caused zinc deficiency in both diabetic and non-diabetic animals, altering many factors such as growth rate, blood glucose, zinc status, carbohydrate metabolism, and certain enzyme activities. However, zinc supplementation had ameliorative effects by reducing diabetes development caused by calcium that was above normal feed levels.

\section{Acknowledgements}

Thanks are given to the Ministry of Higher Education and scientific research for the fund support and Pasteur Institute for providing rats.

\section{Conflicts of Interest}

Authors declare that no conflict of interest.

\section{Funding Source Declaration}

This study was supported by a research project under the number: F01120140045 funded by the ministry of Higher Education and Scientific Research, Algeria.

\section{References}

1. Carlos Alberto YW, Helena Maria TB, Carmen RV (2015) GABAergic modulation in diabetic encephalopathy-related depression. Curr Pharm Des 21: 4980-4988.
2. Arshag $D$ Mooradian, Mark $F$, Byron $H$, Melinda $M$, Wylie-Rosett J (1994) Selected vitamins and minerals in diabetes. Diabetes Care 17: 464-479.

3. Hira Z, Munir AS, Fatma H, Muhammad AM (2012) Inhibition of protein glycation and advanced glycation end products by ascorbic acid. Afr J Biotechnol 11: 11309-11314.

4. Bertini I, Luchinat C, Monnanni R (1985) Zinc enzymes. J Chem Educ 62: 924-927.

5. Afkhami MA, Mahdi K, Seid Mohammad M, Forough N (2008) Effect of zinc sulfate supplementation on lipid and glucose in type 2 diabetic patients. Pak J Nutr 7: 550-553.

6. Yang VL (2014) Zinc and insulin in pancreatic beta-cells. Endocrine 45: 178-189.

7. Scott DA, Fisher AM (1935) Crystalline insulin. Biochem J 29: 1048-1054.

8. Kechrid Z, Nazan D, Abdennour C, Bouzerna N (2002) Effect of dietary zinc intake on the zinc and carbohydrate metabolism in rats. Turkish Journal of Medical Sciences 32: 101-105.

9. Himoto T, Yoneyama H, Deguchi A, Kurokohchi K, Inukai $M$, et al. (2010) Insulin resistance derived from zinc deficiency in non-diabetic patients with chronic hepatitis C. Exp Ther Med 1: 707-711.

10. Ferdousi S, Mollah FH, Mia MAR (2010) Serum levels of zinc and magnesium in newly diagnosed type-2 diabetic subjects. Bangladesh J Med Biochem 3: 46-49.

11. Hajo H, Silke O, Lothar R (2008) Zinc supplementation for the treatment or prevention of disease: Current status and future perspectives. Exp Gerontol 43: 394-408.

12. Jane H Kass-Wolff (2004) Calcium in women: Healthy bones and much more. J Obstet Gynecol Neonatal Nurs 33: 21-33.

13. Munro $P$ (2010) Calcium metabolism in health and disease. Clin J Am Soc Nephrol 5: S23-S30.

14. Kenney MA, McCoy H (1997) Adding zinc reduces bone strength of rats fed a low-calcium diet. Biological Trace Element Research 58: 35.

15. Spencer H, Rubio N, Kramer L, Norris C, Osis D (1987) Effect of zinc supplements on the intestinal absorption of calcium. J Am Coll Nutr 6: 47-51.

16. Dorota S, Barbara B, Andrzej T, Marzena K, Pawel R, et al. (2011) The effect of zinc-and copper sulphate supplementation on tumor and hair concentrations of trace element ( $\mathrm{Zn}, \mathrm{Cu}, \mathrm{Fe}, \mathrm{Ca}, \mathrm{Mg}, \mathrm{P}$ ) in rats with DMBA-induced breast cancer. Pol J Environ Stud 20: 1585-1592.

17. Adham NF, Song MK (1980) Effect of calcium and copper on zinc absorption in the rat. Nutr Metab 24: 281-290.

18. Wood RJ, Zheng JJ (1997) High dietary calcium intakes reduce zinc absorption and balance in humans. Am J Clin Nutr 65: 1803-1809.

19. Bellis DB, Philip JMcL (1957) Effect of zinc, calcium and phosphous on the skin and growth of pigs. J Sci Food Agric 8: 5119-5127.

20. Southon S, Gee JM, Johnson IT (1984) Hexose transport and mucosal morphology in the small intestine of the zinc-deficient rat. Br J Nutr 52: 371-380.

21. Fatmi W, Kechrid Z, Naziroglu M, Flores-Arce M (2013) Selenium supplementation modulates zinc levels and antioxidant values in blood and tissues of diabetic rats fed zinc deficient diet. Biol Trace Elem Res 152: 243-250. 
22. Nelson RL, Tanure JC, Andrianopoulos G (1987) The effect of dietary milk and calcium on experimental colon carcinogenesis. Dis Colon Rectum 30: 947-949.

23. Derouiche S, Kechrid Z (2016) Zinc supplementation overcomes effects of copper on zinc status, carbohydrate metabolism and some enzyme activities in diabetic and non-diabetic Rats. Can J Diabetes 40: 342-347.

24. Southon S, Kechrid Z, Wright AJ, Fairwrather-Tait SJ (1988) Effect of reduced dietary zinc intake on carbohydrate metabolism in the genetically diabetic mouse (C57BL/ KsJ db+/db+). Br J Nutr 60: 499-507.

25. Haidari F, Shahi MM, Zarei M, Rafiei H, Omidian K (2012) Effect of green tea extract on body weight, serum glucose and lipid profile in streptozotocin-induced diabetic rats. A dose response study. Saudi Med J 33: 128-133.

26. Kechrid Z, Derai EH, Layachi N (2007) The beneficial effect of vitamin $E$ supplementation on zinc status, carbohydrate metabolism, transaminases and alkaline phosphatase activities in alloxan-diabetic rats fed on zinc deficiency diet. Int J Diabetes Metabolism 15: 46-50.

27. Sergeev IN, Song Q (2014) High vitamin D and calcium intakes reduce diet-induced obesity in mice by increasing adipose tissue apoptosis. Mol Nutr Food Res 58: 13421348.

28. Payahoo L, Ostadrahimi A, Mobasseri M, Khaje Bishak $Y$, Farrin N, et al. (2013) Effects of zinc supplementation on the anthropometric measurements, lipid profiles and fasting blood glucose in the healthy obese adults. Adv Pharm Bull 3: 161-165.

29. Velloso CP (2008) Regulation of muscle mass by growth hormone and IGF-1. Br J Pharmacol 154: 557-568.

30. Ajibola RS, Ogundahunsi OA, Soyinka OO, EO Ogunyemi, AO Odewabi (2014) Serum chromium, molybdenum, zinc and magnesium levels in diabetes mellitus patients in sagamu, south west Nigeria. Asia J Med Sci 6: 15-19.

31. Chao-Xia Y, Yong-Jian L, Kang-Sen M, Zhen-Yu D, Hui-Jun $Y$, et al. (2006) Effect of dietary calcium and phosphorus on growth, feed efficiency, mineral content and body composition of juvenile grouper, Epinephelus coioides. Aquaculture 255: 263-271.

32. Mace GB, Shannon A (2000) Calcium control of zinc uptake in rainbow trout. Aquat Toxicol 50: 257-264.

33. Ozcelik D, Nazıroglu M, Tuncdemir M, Çelik Ö, Öztürk M, et al. (2012) Zinc supplementation attenuates metallothionein and oxidative stress changes in kidney of streptozotocin induced diabetic rats. Biol Trace Elem Res 150: 342-349.

34. Grodsky GM, Schmid FF (1985) Kinetic and quantitative relationship between insulin release and ${ }^{65} \mathrm{Zn}$ efflux from perfused islet. Endocrinology 117: 704-710.

35. Chausmer AB (1998) Zinc, insulin and diabetes. J Am Coll Nutr 17: 109-115.

36. Elizabeth AF, Brendan L (1994) Effects of calcium antagonists on insulin-mediated glucose metabolism in skeletal muscle. Diabetes 43: 73-79.

37. Lanner JT, Katz A, Tavi P, Sandström ME, Zhang SJ, et al. (2006) The role of $\mathrm{Ca}^{2+}$ influx for insulin-mediated glucose uptake in skeletal muscle. Diabetes 55: 2077-2083.

38. Bellomo E, Massarotti A, Hogstrand C, Maret W (2014) Zinc ion modulates protein tyrosine phosphatase $1 \mathrm{~B}$ activity. Metallomics 6: 1229-1239.

39. Ranasinghe P, Pigera S, Galappatthy P, Katulanda P, Constantine GR (2015) Zinc and diabetes mellitus: Understanding molecular mechanisms and clinical implications. Daru 23: 44.

40. Derouiche S, Azzi M, Hamida A (2017) Effect of extracts aqueous of phragmites australis on carbohydrate metabolism, some enzyme activities and pancreatic islet tissue in alloxan induced diabetic rats. Int J Pharm Pharm Sci 9: 54-58.

41. Kechrid Z, Bouzerna N (2004) Effect of zinc deficiency and experimental diabetes on glutamate oxaloacetate, glutamate pyruvate aminotransferases and alkaline phosphatase activities in rats. Int J Diabetes Metabolism 11: 14-18.

42. Grefley S, Sandstead H (1993) Oxidation of alanine and B-hydroxybutyrate in late gestation by zinc restricted in rats. Nutrition 113: 1803-1810.

43. Matthias KD, Schulz Georg E (1996) Catalytic mechanism of the metal-dependent fuculose aldolase from Escherichia coli as derived from the structure. J Mol Biol 259: 458-466.

44. Jamshid GG, Karamouz H, Agdam H Shahriar, Hossein Zadeh AN, Rahim B, et al. (2011) Effect of inorganic zinc supplement on activity of alkaline phosphatase enzyme as an index of mucosal functional in small intestine of male broilers. American-Eurasian J Agric Environ Sci 11: 622-625.

45. Sarker MSA, Satoh S (2009) Effect of dietary phosphorus and zinc levels on hematocrit value, plasma mineral content and plasma alkaline phosphatase activity of fingerling rainbow trout, oncorhynchus mykiss. Progress Agric 20: 183-192. 